\title{
Surface Plasmon Resonance Imaging biosensor for cystatin determination based on the application of bromelain, ficin and chymopapain
}

\author{
Ewa Gorodkiewicz ${ }^{1}$, Joanna Breczko², Anna Sankiewicz ${ }^{1}$ \\ ${ }^{1}$ Department of Electrochemistry, Institute of Chemistry, University of Bialystok, Poland \\ ${ }^{2}$ Department of Physicochemical Analysis, Institute of Chemistry, University of Bialystok, Poland
}

\begin{abstract}
A Surface Plasmon Resonance Imaging (SPRI) sensor based on bromelain or chymopapain or ficin has been developed for specific cystatin determination. Cystatin was captured from a solution by immobilized bromelain or chymopapain or ficin due to the formation of an enzyme-inhibitor complex on the biosensor surface. The influence of bromelain, chymopapain or ficin concentration, as well as the $\mathrm{pH}$ of the interaction on the SPRI signal, was investigated and optimized. Sensor dynamic response range is between $0-0.6 \mu \mathrm{g} / \mathrm{ml}$ and the detection limit is equal to $0.1 \mu \mathrm{g} / \mathrm{ml}$. In order to demonstrate the sensor potential, cystatin was determined in blood plasma, urine and saliva, showing good agreement with the data reported in the literature. (Folia Histochemica et Cytobiologica 2012, Vol. 50, No. 1, 130-136)
\end{abstract}

Key words: SPRI biosensor, cystatin, bromelain, ficin, chymopapain

\section{Introduction}

Cystatins are a widespread group of proteins with protective and control functions. They are cysteine protease inhibitors such as cathepsins which protect organisms from the dangerous activity of enzymes and reduce the risk of diseases. Lowered or raised concentrations of cystatin may be a symptom of many disorders [1-3]. Located in the human body, where cystatin is present, are the secreted tissue of epithelium cells, nervous tissue, prostate cells and body fluids $[4,5]$. Its shortage or excess may indicate some sicknesses $[4,6]$. The normal cystatin range in blood plasma is $0.53-0.92$ $\mu \mathrm{g} / \mathrm{ml}$, and a lower concentration of this protein may indicate cancerous diseases $[7,8]$. The normal

Correspondence address: E. Gorodkiewicz,

Department of Electrochemistry,

Institute of Chemistry, University of Bialystok, Al. J. Pilsudskiego 11/4, 15-443 Bialystok, Poland; tel.: + 488574576 01, fax: + 488574701 13; e-mail: ewka@uwb.edu.pl range level of cystatin in human saliva is $0.36-4.8$ $\mu \mathrm{g} / \mathrm{ml}$; values below this range indicate a caries occurrence $[9,10]$. Human urine cystatin concentration varies between 0.033 and $0.29 \mu \mathrm{g} / \mathrm{ml}$. A higher cystatin level in urine is characteristic of people with kidney disease or of older age [11].

Cystatin $\mathrm{C}$ is one of the representatives of the cystatin superfamily. It is a low molecular weight protein $(\mathrm{M}=13.3 \mathrm{kDa})$ and consists of a single polypeptide chain containing 120 aminoacids. It is produced by all nucleated cells in the body and secreted into the extracellular matrix in invariant quantities [12]. Cystatin $\mathrm{C}$ is freely filtered by the glomerulus and undergoes resorption and degradation in proximal tubular cells. The blood level of this protein is correlated with the glomerular filtration rate and can be used as a marker of the glomerular filtration rate (GFR). Measurement of the cystatin $\mathrm{C}$ level is simpler and more effective than the determination of creatinine. Recently, it has been shown that determination of cystatin $C$ in serum is a better marker of GFR than serum creatinine $[13,14]$. 
The Surface Plasmon Resonance Imaging technique has been successfully applied for the determination of biologically active substances such as cathepsins B [15], G [16], and D, E [17]. These determinations were performed by the application of highly specific biosensors for each kind of cathepsin. Biosensors were prepared by immobilization onto gold chip surface inhibitors specific for each kind of cathepsin. Due to the specific interaction of the immobilized inhibitor with a specific cathepsin, only this cathepsin is captured and then determined by SPRI. Immobilized cystatin was applied for cathepsin determination [15]. However, the same interaction can be used for cystatin determination.

Bromelain, ficin and chymopapain are a family of enzymes known as the cysteine proteases. The action mechanism of these enzymes is quite similar. Of this group, only bromelain is widely known and applied.

Bromelain (E.C. 3.4.22.4) belongs to a papain superfamily, but differs from the other members of the superfamily in terms of the amino acid sequence [18]. Bromelain is a $23.8 \mathrm{kDa}$ - basic thiol protease which contains 212 amino acid residues with a single $\mathrm{N}$-glycoside oligosaccharide chain [19-21]. Bromelain can be isolated from pineapple (Ananas comosus) [22, 23]. It is worth stressing that bromelain has a therapeutic application [22, 24, 25].

Ficin (EC 3.4.22.3) is also a cysteine sulfhydryl enzyme which is isolated from fig latex. It is very often used for differentiating blood group antigens. As with bromelain or papain, ficin takes part in esters hydrolysis and catalyzes the process of peptide synthesis [26]. Ficin predicts the degradability of proteins of ruminal feeds [27].

Chymopapain (EC 3.4.22.6) is a plant cysteine protease obtained from the latex of the Carica papaya [28]. It is provided as a mixture of proteolytic enzymes [29] or its salts [30]. This enzyme has some biomedical applications $[29,30]$. Application of chymopapain decreased dramatically after reports of side effects [29]. Chymopapain is used in contact lens liquids [31].

The pharmaceutical application of the papain group of enzymes is limited because of the relatively poor stability of the aqueous solutions [32].

The aim of this paper was the manufacture of biosensors for cystatin determination on the basis of specific cystatin interaction with bromelain or ficin or chymopapain. The further aim was optimization of biosensor conditions, demonstration of the ability for determination of cystatin in body fluids, such as blood plasma, urine and saliva, as well as comparison of three developed biosensors.

\section{Material and methods}

Chemicals and materials. Cysteamine hydrochloride, cystatin from chicken egg white $(12.5 \mathrm{kDa})$, human albumin, bromelain from pineapple stem, ficin from fig tree latex, chymopapain from papaya latex, N-Ethyl-N'-(3-dimethyl aminopropyl) carbodiimide (EDC), HEPES sodium salt (all SIGMA, Steinheim, Germany) and N-Hydroxysuccinimide (NHS) (ALDRICH, Munich, Germany) were used, as well as dichloroethane of HPLC grade (FLUKA, Munich, Germany), absolute ethanol, sodium hydroxide, sodium chloride, sodium carbonate, sodium phosphate, potassium phosphate, sodium acetate, potassium chloride, magnesium chloride (all POCh, Gliwice, Poland), acetic buffer $\mathrm{pH}=3.79-5.57$, Phosphate Buffered Saline (PBS) $\mathrm{pH}=7.2$ (BIOMED, Lublin, Poland), phosphate buffer $\mathrm{pH}=7.17-8.04$, and carbonate buffer $\mathrm{pH}=8.50-9.86$. Photopolymer ELPEMER SD 2054 and hydrophobic protective paint SD 2368 UV SG-DG (PETERS, Kempen, Germany) chemicals were used as received. Aqueous solutions were prepared with filtered milliQ water (Simplicity®MILLIPORE).

Blood samples were taken from the Blood Donor Center at Bialystok, Poland. Urine samples were taken from healthy people younger and older than 75 . Saliva samples were taken from healthy people.

Procedures. Chip preparation. Glass plates with layers of chromium and gold were manufactured as described in a previous paper [33]. The gold surface of the chip was covered with photopolymer and hydrophobic paint as described in a previous paper [34]. The chip has four parts of 12 free gold surfaces. Twelve single SPRI measurements can be performed for a single sample. Measurements can be done without mixing the tested solutions.

Enzyme immobilization. Chips were rinsed with ethanol and water and dried under a stream of nitrogen. They were then immersed in $20 \mathrm{mM}$ of cysteamine ethanolic solutions for $2 \mathrm{~h}$ and then rinsed with ethanol and water and once again dried under a stream of nitrogen. Bromelain was activated with NHS (50 mM) and EDC (200 mM) solution in a carbonate buffer $(\mathrm{pH}=8.5)$ environment and incubated on the aminemodified surface at $37^{\circ} \mathrm{C}$ for $1 \mathrm{~h}[33,34]$. Ficin and chymopapain were immobilized in the same way.

SPRI measurements. SPRI measurements were performed as described in a previous paper [33, 34]. Reflectivity was simultaneously measured across an entire chip surface at a fixed angle of incident light for different samples and depends on the kind and number of biomolecules captured by the sensor. The contrast values obtained for all pixels across a particular sample spot were integrated. Thus the SPRI signal was integrated over the spot area. NIH Image J version 1.32 software was used to evaluate the SPRI images in 2D form. 
Preparation of biological samples. Blood plasma. Samples of blood plasma were prepared as described in a previous paper [35]. $2 \mathrm{ml}$ of blood was centrifuged and filtered for blood plasma separation from hemoglobin. The prepared plasma of blood was diluted twice with a PBS buffer and transferred onto the sensor surface for 10 minutes. After interaction, the surface of the biosensor was washed six times with HEPES buffer. The concentration was evaluated using a chicken egg white cystatin calibration curve.

Urine. Samples of urine were prepared as described in a previous paper [35]. Urine was centrifuged and the supernatant filtered. Prepared urine samples were transferred onto the sensor surface for 10 minutes. After interaction, the surface of the biosensor was washed six times with the HEPES buffer. The concentration was evaluated using a chicken egg white cystatin calibration curve.

Saliva. Samples of saliva were prepared as described in a previous paper [35]. $3 \mathrm{ml}$ of saliva was centrifuged and the supernatant filtered. Prepared saliva samples were diluted five times with a PBS buffer and transferred onto the sensor surface for 10 minutes. After interaction, the surface of the biosensor was washed six times with the HEPES buffer. The concentration was evaluated using a chicken egg white cystatin calibration curve.

\section{Results}

\section{The influence of bromelain, chymopapain and ficin concentration on the analytical signal of cystatin}

The purpose of these experiments was the selection of the optimal conditions for cystatin determination, separately for bromelain, chymopapain and ficin.

The influence of bromelain, chymopapain and ficin concentration on the SPRI signal was studied separately for each enzyme. The experiments were performed at constant cystatin concentration. Eight enzyme solutions with different concentrations $(0.2 ; 0.38 ; 0.75 ; 1.0$; $1.5 ; 2.0 ; 2.25 ;$ and $3.0 \mu \mathrm{g} / \mathrm{ml}$ ), preliminarily activated with NHS and EDC, were transferred onto different places on the chip surface modified by cysteamine. After enzyme immobilization, the chip was treated with the chicken egg white cystatin solution $(0.75 \mu \mathrm{g} / \mathrm{ml})$. The time of the interaction was 10 minutes. The chip was then rinsed with the HEPES buffer, dried and the SPRI measurement performed. The results are shown in Figure 1. Curves ',b' and ',a' are shifted upwards in order to avoid coincidence of these curves with curve ',c'. The obtained curve shape is of a Langmuir isotherm type. The plateau of the signal is observed for enzyme concentration above $1 \mathrm{mg} / \mathrm{ml}$. Concentration of bromelain, chymopapain and ficin equal to $1.5 \mu \mathrm{g} / \mathrm{ml}$ was selected as optimal for further investigation.

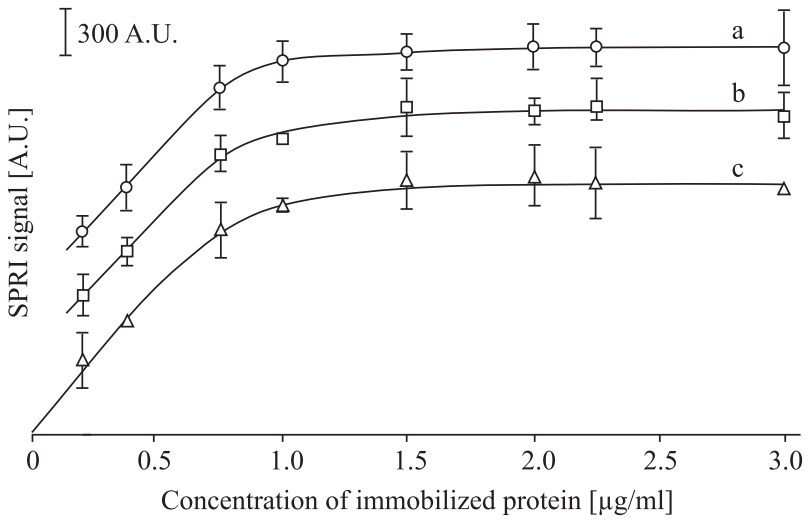

Figure 1. Dependence of the enzyme - cystatin complex SPRI signal (arbitrary units) on inhibitor concentration: (a) bromelain, (b) ficin, (c) chymopapain. Initial cystatin concentration: $0.75 \mu \mathrm{g} / \mathrm{ml}$. Initial $\mathrm{pH}$ of cystatin solution: 7.0

\section{The influence of solution $\mathrm{pH}$ on the interaction process}

The influence of $\mathrm{pH}$ of a cystatin solution on the SPRI signal was studied within a range of 1.0-11.0 at constant concentrations of bromelain, chymopapain or ficin $(1.5 \mu \mathrm{g} / \mathrm{ml})$ and cystatin $(0.75 \mu \mathrm{g} / \mathrm{ml})$. Solutions of the enzyme preliminarily activated with EDC and NHS were transferred onto different places on the chip surface modified by cysteamine. After inhibitor immobilization, the biosensor was treated for $10 \mathrm{~min}$ utes with chicken egg white cystatin solutions having different $\mathrm{pH}$ values. Results are shown in Figure 2. The obtained figure shows that the maximum of the SPRI signal for the enzyme - cystatin complex is between 6.3 and 6.6. The value of $\mathrm{pH}=6.5$ was selected as optimal for further investigation.

\section{Analytical response of the developed three sensors to cystatin concentration. Calibration curve}

A response of the analytical SPRI signal for chicken egg white cystatin concentration was measured within the range of cystatin concentration between 0.1 and $1.4 \mu \mathrm{g} / \mathrm{ml}$ at the same $\mathrm{pH}$ value (6.5). The chip surfaces modified by cysteamine were covered by layers of ficin $(1.5 \mu \mathrm{g} / \mathrm{ml})$. Cystatin solutions with different concentrations were put on immobilized ficin for 10 minutes. The obtained calibration curve is shown in Figure 3a. The experiments with chymopapain and bromelain were performed analogically. The results are shown in Figures $3 \mathrm{~b}$ and $3 \mathrm{c}$ respectively.

\section{Specificity of the enzyme - cystatin interaction}

Specificity of the interaction between bromelain, ficin, chymopapain and cystatin was verified through 


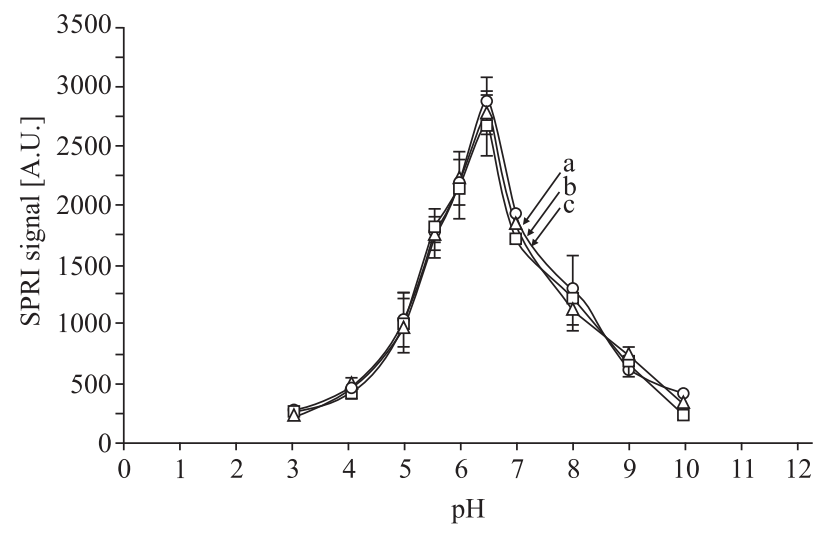

Figure 2. Dependence of the enzyme - cystatin complex SPRI signal (arbitrary units) on pH. Initial (a) bromelain, (b) chymopapain, (c) ficin concentration: $1.5 \mu \mathrm{g} / \mathrm{ml}$. Initial cystatin concentration: $0.75 \mu \mathrm{g} / \mathrm{ml}$

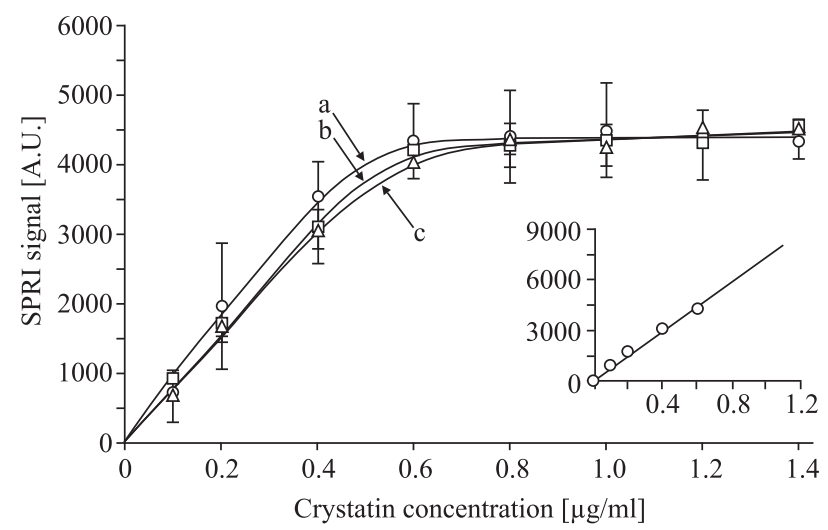

Figure 3. The dependence of the enzyme - cystatin complex SPRI signal (arbitrary units) on cystatin concentration. The initial enzyme (a) ficin, (b) chymopapain, (c) bromelain concentration: $1.5 \mu \mathrm{g} / \mathrm{ml}$. The initial $\mathrm{pH}$ value of cystatin solution: 6.5. (a) Example linear section of curve (a); concentration range $0-0.6 \mu \mathrm{g} / \mathrm{ml}$

treating a surface of the chip with immobilised enzyme layer $(1.5 \mu \mathrm{g} / \mathrm{ml})$ by human albumin $(0.4 \mu \mathrm{g} /$ $/ \mathrm{ml})$, free chicken egg white cystatin $(0.4 \mu \mathrm{g} / \mathrm{ml})$ and an enzyme-cystatin complex $(0.4: 0.7 \mu \mathrm{g} / \mathrm{ml})$. The time of the interaction was 10 minutes. Results are shown in Figure 4.

\section{Precision of the developed method for cystatin determination}

Precision of the developed method was tested under optimal conditions ( $\mathrm{pH}$ of cystatin solution: 6.5, bromelain, ficin, chymopapain concentration: $1.5 \mu \mathrm{g} / \mathrm{ml}$ ) for the concentration of chicken egg white cystatin equal to $0.4 \mu \mathrm{g} / \mathrm{ml}$. The results of measurements are shown in Table 1.
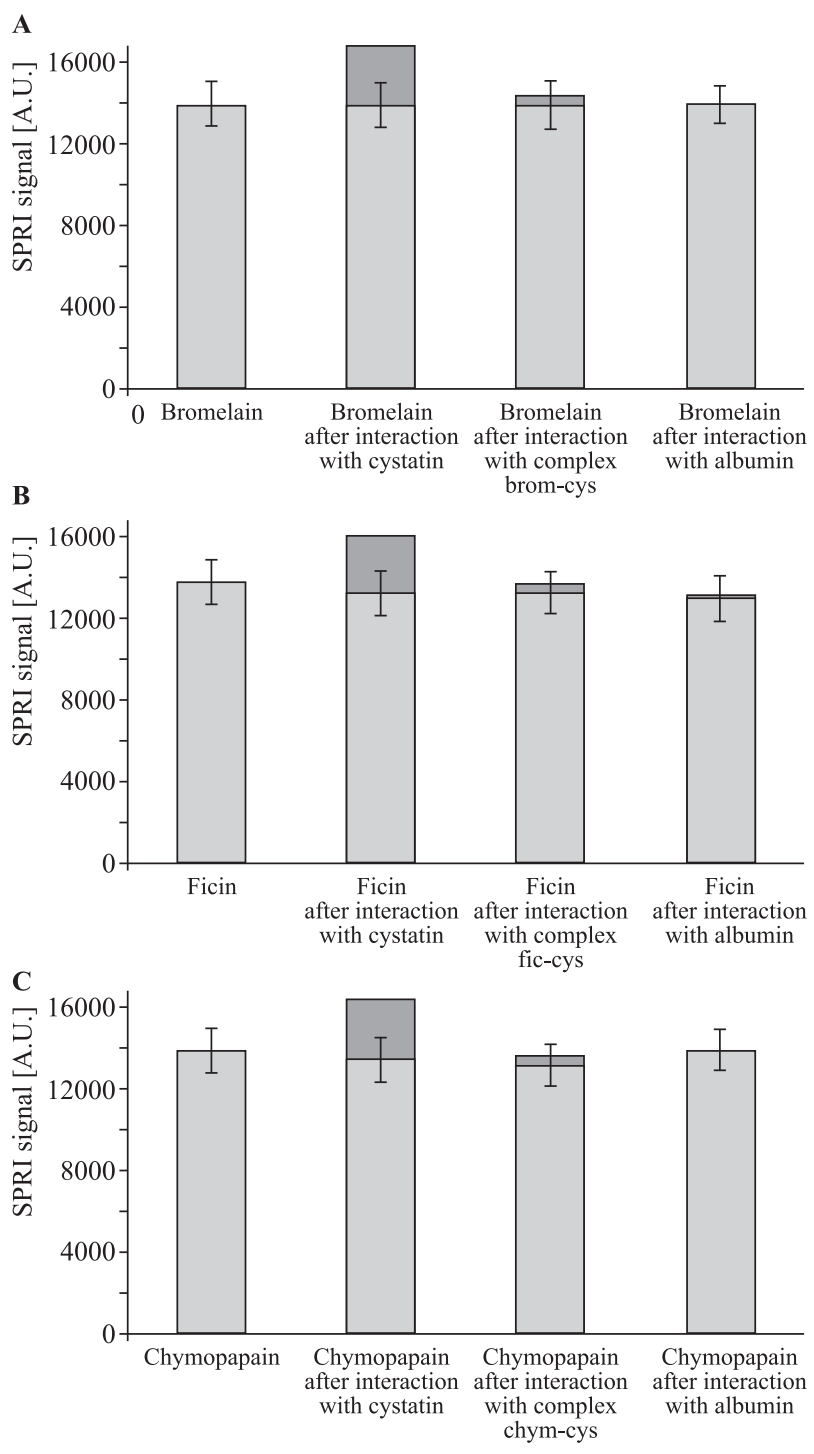

Figure 4. SPRI signals corresponding to the interaction between immobilized enzyme: (a) bromelain, (b) ficin, (c) chymopapain, and different molecules (chicken egg white cystatin or complex cystatin with bromelain or human albumin). Initial concentration of enzyme: $1.5 \mu \mathrm{g} / \mathrm{ml}$. Initial concentration of cystatin and albumin: $0.4 \mu \mathrm{g} / \mathrm{ml}$.

The initial $\mathrm{pH}$ value of cystatin and albumin solutions: 6.5

\section{Cystatin determination in real samples}

\section{Blood plasma samples}

Samples of blood plasma from nine healthy adult donors were analyzed using the developed sensors for cystatin determination. The results are shown in Table 2.

\section{Urine samples}

The developed sensor was also used to determine cystatin concentration in urine. Samples were taken 
Table 1. Precision of measurement of concentration of chicken egg white cystatin

\begin{tabular}{|l|c|c|c|c|c|c|c|}
\hline $\begin{array}{l}\text { Chicken egg } \\
\text { white cystatin }\end{array}$ & No of meas. & $\begin{array}{c}\text { Added } \\
{[\mu \mathrm{g} / \mathbf{m l}]}\end{array}$ & $\begin{array}{c}\text { Found } \\
{[\boldsymbol{\mu} \mathbf{g} / \mathbf{m l}]}\end{array}$ & $\begin{array}{c}\text { Recovery } \\
(\boldsymbol{\%})\end{array}$ & $\begin{array}{c}\text { S.D. } \\
{[\mu \mathrm{g} / \mathrm{ml}]}\end{array}$ & $\begin{array}{c}\text { RSD } \\
(\boldsymbol{\%})\end{array}$ & $\begin{array}{c}\text { Confidence limit } \\
(\mathbf{9 5 \%})[\boldsymbol{\mu} / \mathbf{m l}]\end{array}$ \\
\hline $\begin{array}{l}\text { Sensor based on } \\
\text { bromelain }\end{array}$ & 24 & 0.400 & 0.390 & 97.50 & 0.04 & 10.3 & 0.08 \\
\hline $\begin{array}{l}\text { Sensor based on } \\
\text { ficin }\end{array}$ & 24 & 0.400 & 0.386 & 96.50 & 0.03 & 7.8 & 0.06 \\
\hline $\begin{array}{l}\text { Sensor based } \\
\text { on chymopapain }\end{array}$ & 24 & 0.400 & 0.387 & 96.75 & 0.05 & 12.9 & 0.10 \\
\hline
\end{tabular}

Table 2. Cystatin concentration in blood plasma of healthy donors as determined using three different sensors

\begin{tabular}{|l|c|c|c|}
\hline \multirow{2}{*}{ Donor number } & \multicolumn{3}{|c|}{ Cystatin concentration in blood plasma $[\boldsymbol{\mu g} / \mathbf{m l}]$} \\
\cline { 2 - 4 } & Sensor based on bromelain & Sensor based on ficin & Sensor based on chymopapain \\
\hline $\mathbf{1}$ & $0.75 \pm 0.05$ & $0.76 \pm 0.06$ & $0.74 \pm 0.05$ \\
\hline $\mathbf{2}$ & $0.79 \pm 0.04$ & $0.79 \pm 0.05$ & $0.80 \pm 0.04$ \\
\hline $\mathbf{3}$ & $0.70 \pm 0.04$ & $0.71 \pm 0.08$ & $0.70 \pm 0.04$ \\
\hline $\mathbf{4}$ & $0.62 \pm 0.06$ & $0.61 \pm 0.05$ & $0.63 \pm 0.04$ \\
\hline $\mathbf{5}$ & $0.59 \pm 0.05$ & $0.62 \pm 0.07$ & $0.62 \pm 0.02$ \\
\hline $\mathbf{6}$ & $0.73 \pm 0.06$ & $0.71 \pm 0.05$ & $0.72 \pm 0.04$ \\
\hline $\mathbf{7}$ & $0.88 \pm 0.05$ & $0.86 \pm 0.03$ & $0.89 \pm 0.04$ \\
\hline $\mathbf{8}$ & $0.76 \pm 0.04$ & $0.76 \pm 0.03$ & $0.75 \pm 0.06$ \\
\hline $\mathbf{9}$ & $0.88 \pm 0.02$ & $0.87 \pm 0.08$ & $0.88 \pm 0.04$ \\
\hline
\end{tabular}

from people younger and older than 75 . The results are shown in Table 3.

\section{Saliva samples}

Cystatin was determined in six samples of saliva in order to demonstrate the developed sensor applicability for this purpose. The results are shown in Table 4.

\section{Discussion}

All three calibration curves of chicken egg white cystatin are of the Langmuir's isotherm type (see Figure 3). The roughly linear sections of these curves (following Henry's isotherm) is within the range of $0-0.6 \mu \mathrm{g} / \mathrm{ml}$ $(0-45 \mathrm{mM})$ and are useful for analytical purposes (see the example of the section of curve ' $a$ '). It is worth stressing that calibration curves for three sensors are almost identical and are indistinguishable due to precision error.

As can be concluded from Figure 4, the developed sensor reacts to free cystatin and, to a much smaller degree, to the presence of cystatin bounded in the complex with bromelain, ficin or chymopapain. The bars corresponding to the analytical signals of complex are significantly lower than the signals for free cystatin. This is evidence that the complexes of bromelain, ficin or chymopapain are stable (dissociation constans $8.4 \cdot 10^{-8}$ $\mathrm{M}$ for ficin, $9.5 \cdot 10^{-8} \mathrm{M}$ for bromelain [36] and $9 \cdot 10^{-13} \mathrm{M}$ for chymopapain [37]). Any response to human albumin was not observed, which is evidence of the specificity of the enzyme - cystatin interaction.

The results in Table 1 show that the precision of SPRI measurement using the developed biosensor is $10.3 \%$ for sensor based on bromelain, $7.8 \%$ on ficin and $12.9 \%$ on chymopapain, which are values typical for trace analysis. Confidence limits of the results $(0.08 \mu \mathrm{g} / \mathrm{ml}$ for bromelain, $0.06 \mu \mathrm{g} / \mathrm{ml}$ for ficin and $0.10 \mu \mathrm{g} / \mathrm{ml}$ for chymopapain) can be easily narrowed by the application of measurement repetitions at the same chip surface.

All three sensors gave very similar results concerning cystatin concentration in the blood plasma of healthy donors (see Table 2). The obtained results for cystatin in the blood plasma are within a range between 0.59 and $0.88 \mu \mathrm{g} / \mathrm{ml}$. All results are within the norm range $(0.53-0.92 \mu \mathrm{g} / \mathrm{ml})$ reported in the literature $[7,8]$.

In all cases, the results concerning the cystatin concentration in the urine of donors younger and older than 75 obtained with three sensors exhibit similar values (see Table 3). The cystatin level in all investigated urine samples was within the norm range 
Table 3. Cystatin concentration in urine of donors younger and older than 75

\begin{tabular}{|l|c|c|c|}
\hline \multirow{2}{*}{ Donors under 75 number } & \multicolumn{3}{|c|}{ Cystatin concentration in urine $[\boldsymbol{\mu g} / \mathbf{m l}]$} \\
\cline { 2 - 4 } & Sensor based on bromelain & Sensor based on ficin & Sensor based on chymopapain \\
\hline $\mathbf{1}$ & $0.091 \pm 0.004$ & $0.091 \pm 0.004$ & $0.092 \pm 0.001$ \\
\hline $\mathbf{2}$ & $0.101 \pm 0.010$ & $0.100 \pm 0.006$ & $0.103 \pm 0.008$ \\
\hline $\mathbf{3}$ & $0.155 \pm 0.001$ & $0.154 \pm 0.002$ & $0.153 \pm 0.005$ \\
\hline $\mathbf{4}$ & $0.132 \pm 0.001$ & $0.132 \pm 0.003$ & $0.131 \pm 0.006$ \\
\hline $\mathbf{5}$ & $0.142 \pm 0.010$ & $0.136 \pm 0.006$ & $0.136 \pm 0.002$ \\
\hline Donors over 75 & & & Sensor based on chymopapain \\
\hline \multirow{2}{*}{ Donor number } & & Cystatin concentration in urine $[\boldsymbol{\mu g} / \mathbf{m l}]$ & $0.087 \pm 0.003$ \\
\cline { 2 - 4 } & Sensor based on bromelain & Sensor based on ficin & $0.113 \pm 0.012$ \\
\hline $\mathbf{6}$ & $0.080 \pm 0.005$ & $0.081 \pm 0.006$ & $0.129 \pm 0.001$ \\
\hline $\mathbf{7}$ & $0.112 \pm 0.001$ & $0.111 \pm 0.001$ & $0.134 \pm 0.001$ \\
\hline $\mathbf{8}$ & $0.130 \pm 0.008$ & $0.125 \pm 0.004$ & $0.171 \pm 0.010$ \\
\hline $\mathbf{9}$ & $0.132 \pm 0.001$ & $0.132 \pm 0.009$ & $0.174 \pm 0.007$ \\
\hline $\mathbf{1 0}$ & $0.171 \pm 0.007$ & & \\
\hline
\end{tabular}

Table 4. Cystatin concentration in saliva of donors

\begin{tabular}{|l|c|c|c|}
\hline \multirow{2}{*}{ Donor number } & \multicolumn{3}{|c|}{ Cystatin concentration in saliva $[\boldsymbol{\mu g} / \mathbf{m l}]$} \\
\cline { 2 - 4 } & Sensor based on bromelain & Sensor based on ficin & Sensor based on chymopapain \\
\hline $\mathbf{1}$ & $0.60 \pm 0.02$ & $0.58 \pm 0.03$ & $0.58 \pm 0.03$ \\
\hline $\mathbf{2}$ & $0.65 \pm 0.04$ & $0.66 \pm 0.03$ & $0.68 \pm 0.02$ \\
\hline $\mathbf{3}$ & $0.65 \pm 0.02$ & $0.66 \pm 0.02$ & $0.67 \pm 0.04$ \\
\hline $\mathbf{4}$ & $0.49 \pm 0.04$ & $0.47 \pm 0.01$ & $0.47 \pm 0.03$ \\
\hline $\mathbf{5}$ & $0.79 \pm 0.05$ & $0.77 \pm 0.03$ & $0.78 \pm 0.05$ \\
\hline $\mathbf{6}$ & $0.57 \pm 0.05$ & $0.56 \pm 0.05$ & $0.57 \pm 0.03$ \\
\hline
\end{tabular}

$(0.033-0.29 \mu \mathrm{g} / \mathrm{ml})$ reported in the literature $[9,11]$. Theoretically, urine from older people should contain higher cystatin concentrations, but this is not the rule and may depend on many factors [9].

In all cases, the results concerning the cystatin concentration in the saliva of donors obtained with three different sensors exhibit similar values (see Table 4). The norm range of cystatin concentration in saliva reported in the literature is between 0.36 and $4.8 \mu \mathrm{g} / \mathrm{ml}$ and all measured values are within this range [9]. Higher cystatin concentration in saliva could be a caries symptom [10].

\section{Conclusions}

Three SPRI biosensors specific for cystatin determination, based on the interaction between immobilized bromelain, ficin or chymopapain with cystatin, have been developed.

All three developed biosensors ensure the specific analytical response of cystatin. The optimum $\mathrm{pH}$ for all three biosensors is between 6.3 and 6.6. Calibration curves of cystatin for all three biosensors are almost identical and exhibit a Langmuir type with a roughly linear section between 0.1 and $0.6 \mu \mathrm{g} / \mathrm{ml}$. All three developed biosensors can be used successfully for the determination of cystatin concentration in body fluids such as saliva, blood or urine.

\section{Acknowledgements}

Prof. Pawel Kafarski, Prof. Marek Bryjak from Wroclaw University of Technology and Prof. Zenon Lukaszewski from Poznan University of Technology 
are greatly acknowledged for their very fruitful consultations. Prof. Zbigniew Artur Figaszewski from the University in Bialystok is also greatly acknowledged for creating a stimulating climate for our research. MSc. Kazimierz Wojtulewski is acknowledged for technical assistance.

\section{References}

1. Abrahamson M, Alvarez-Fernandez M, Nathanson CJ. Cystatins. Biochem Soc Symp. 2003;70:179-199.

2. Travis J, Potempa J, Maeda H. Are bacterial proteinases pathogenic factors? Trends Microbiol. 1995;3:405-407.

3. Barrett AJ. Cystatin, the egg white inhibitor of cysteine proteinases. Methods Enzymol. 1981;80:771-778.

4. Abrahamson M, Mason RW, Hansson H, Buttle DJ, Grubb A, Ohlsonn K. Human cystatin C role of the $\mathrm{N}$-terminal segment in the inhibition of human cysteine proteinases and in its inactivation by leukocyte elastase. Biochem J. 1991;273:621-626.

5. Jiborn T, Abrahamson M, Wallin H, Malm J, Lundwall K. Cystatin $\mathrm{C}$ is highly expressed in the human male reproductive system. J Androl. 2004;25:564-572.

6. Levy E, Lopez-Otin C, Ghiso J, Geltner D, Frangione B. Stroke in Icelandic patients with hereditary amyloid angiopathy is related to a mutation in the cystatin $\mathrm{C}$ gene, an inhibitor of cysteine proteases. J Exp Med. 1989;1:1771-1778.

7. Finney H, Newman DJ, Price CP. Adult reference ranges for serum cystatin C, creatinine and predicted creatinine clearance. Ann Clin Biochem. 2000;37:49-59.

8. Wyrwińska A, Torliński L. Proteazy cysteinowe i cystatyny w chorobach nowotworowych. Cz. 1. Diagnostyczna i prognostyczna wartość oznaczania cystatyn i/lub proteaz cysteinowych. Nowiny Lekarskie. 2003;72:228-233.

9. Sulicka J, Franczuk P, Rewiuk K. Przydatność oznaczania cystatyny $\mathrm{C}$ w diagnozowaniu niewydolności nerek u osób w starszym wieku. Gerontol Pol. 2005;13:84-87.

10. Kasiak M. Aktywność antypapainowa cystatyn w ślinie mieszanej a próchnica zębów. Den Med Prob. 2006;43:27-31.

11. Filler G, Bökenkamp A, Hofmann W, Le Bricon T, Martínez-Brú C, Grubb A. Cystatin C as a marker of GFR - history, indications, and future research. Clin Biochem. 2005;38:1-8.

12. Newman DJ. Cystatin C. Ann Clin Biochem. 2002;39:89-104.

13. Marchewka Z. Low Molecular Weight Biomarkers in the Nephrotoxicity. Adv Clin Exp Med. 2006;15:1129-1138.

14. Newman DJ, Tanakar H, Edwards RG et al. Serum cystatin-C measured by automated immunoassay: a more sensitive marker of changes in GFR than serum creatinine. Kidney Int. 1995;47:312-318.

15. Gorodkiewicz E. Surface Plasmon Resonance Imaging sensor for cathepsin determination based on immobilized cystatin. Protein Pept Lett. 2009;16:1379-1385.

16. Gorodkiewicz E, Regulska E, Wojtulewski K. Development of an SPR imaging biosensor for determination of cathepsin $\mathrm{G}$ in saliva and white blood cells. Microchim Acta. 2011, in press.

17. Gorodkiewicz E, Regulska E. SPR imaging biosensor for aspartyl cathepsins: sensor development and application for biological material. Protein Pept Let. 2010;17:1148-1154.

18. Ritonja A, Rowan AD, Buttle DJ, Rawlings ND, Turk V, Barret AJ. Stem bromelain: amino acid sequence and implications for weak binding of cystatin. FEBS Lett. 1989;247:419-424.

19. Gupta P, Saleemuddin M. Bioaffinity based oriented immobilization of stem bromelain. Biotechnol Lett. 2006;28:917-922.
20. Rasheedi S, Hag SK, Khan RH. Guanidine hydrochloride denaturation of glycosylated and deglycosylated stem bromelain. Biochemistry (Mosc). 2003;68:1097-1100.

21. Seo H, Itoyama K, Morimoto K, Takagishi T, Oka M, Hayashi T. Spacer effects on enzymatic activity of bromelain immobilized onto porous chitosan beads. Eur Polym J. 1998:34:917-922.

22. Hale LP, Greer PK, Trinh CT, James CL. Proteinase activity and stability of natural bromelain preparations. Int Immunopharm. 2005;5:783-793.

23. Umesh Hebbar H, Sumana B, Raghavarao KSMS. Use of reverse micellar systems for the extraction and purification of bromelain from pineapple wastes. Bioresource Technology. 2008;99:4896-4902.

24. Maurer HR. Bromelain: biochemistry, pharmocology and medical use. Cell Mol Life Sci. 2001;58:1234-1245.

25. Walker AF, Bundy R, Hicks SM, Middleton RW. Bromelain reduces mild acute knee pain and improves well-being in a dose-dependent fashion in an open study of otherwise healthy adults. Phytomedicine. 2002;9:681-686.

26. Tai D-F, Huang H-Y, Huang C-C. Immobilized ficin catalyzed synthesis of peptides in organic solvent. Bioorg Med Chem Lett. 1995;5:1475-1478.

27. Kosmala I, Antoniewicz A, De Boever J, Hvelplund T, Kowalczyk J. Use of enzymatic solubility with ficin (EC 3.4.22.3) to predict in situ feed protein degradability. Anim Feed Sci Technol. 1996;59:245-254.

28. Azarkan M, El Moussaoui A, van Wuytswinkel D, Dehon G, Looze Y. Fractionation and purification of the enzymes stored in the latex of Carica papaya. J Chromatogr $B$. 2003;790:229-238.

29. Chiba K, Masuda K, Andersson GB, Momohara S, Thonar EJ. Matrix replenishment by intervertebral disc cells after chemonucleolysis in vitro with chondroitinase $\mathrm{ABC}$ and chymopapain. Spine J. 2007;7:694-700.

30. Le Goff P, Bourgeois P. Should we accept to stop using chymopapain nucleolysis? Joint Bone Spine. 2002;69:241-243.

31. Diaz-Mochon JJ, Planonth S, Bradley M. From 10,000 to 1: Selective synthesis and enzymatic evaluation of fluorescence resonance energy transfer peptides as specific substrates for chymopapain. Anal Biochem. 2009;384:101-105.

32. Dekeyser PM, Corveleyn S, Demeester J, Remon JP. Stabilization of fully active chymopapain by lyophilization. Int J Pharm. 1997;159:19-25

33. Gorodkiewicz E. The Surface Plasmon Resonance Imaging sensor for papain based on immobilized cystatin. Protein Pept Lett. 2007;14:443-445.

34. Gorodkiewicz E, Fernández-González A, Akkoyun A, Salzer R. Systematic evaluation of a Surface Plasmon Resonance Imaging biochip reader: study of gold surface modifications. Chem Anal (Warsaw). 2005;50:103-116.

35. Gorodkiewicz E, Łuszczyn J. Surface Plasmon Resonance Imaging (SPRI) sensor for cystatin determination based on immobilized papain. Protein Pept Lett. 2011;18:23-29.

36. Rashid F, Sharma S, Bano B. Detailed biochemical characterization of human placental cystatin (HPC). Placenta. 2006;27:822-831.

37. Björk I, Ylinenjärvi K. Interaction between cystatin and the cysteine proteinases actinidin, chymopapain A, and ficin. Biochemistry. 1990;29:1770-1776.

Submitted: 8 March, 2011 Accepted after reviews: 23 November, 2011 